\title{
Concentration of polycyclic aromatic hydrocarbons in water samples from different stages of treatment
}

\author{
Marta Pogorzelec ${ }^{1, *}$, and Katarzyna Piekarska ${ }^{1}$ \\ ${ }^{1}$ Wroclaw University of Science and Technology, Faculty of Environmental Engineering, Wybrzeże \\ Wyspiańskiego 27, 50-370 Wrocław, Poland
}

\begin{abstract}
The aim of this study was to analyze the presence and concentration of selected polycyclic aromatic hydrocarbons in water samples from different stages of treatment and to verify the usefulness of semipermeable membrane devices for analysis of drinking water. For this purpose, study was conducted for a period of 5 months. Semipermeable membrane devices were deployed in a surface water treatment plant located in Lower Silesia (Poland). To determine the effect of water treatment on concentration of PAHs, three sampling places were chosen: raw water input, stream of water just before disinfection and treated water output. After each month of sampling SPMDs were changed for fresh ones and prepared for further analysis. Concentrations of fifteen polycyclic aromatic hydrocarbons were determined by high performance liquid chromatography (HPLC). Presented study indicates that the use of semipermeable membrane devices can be an effective tool for the analysis of aquatic environment, including monitoring of drinking water, where organic micropollutants are present at very low concentrations.
\end{abstract}

\section{Introduction}

Many of organic micropollutants present in potential sources of drinking water e.g. polycyclic aromatic hydrocarbons (PAHs), pesticides, polychlorinated biphenyls (PCBs) and dioxins are considered to be hazardous to human, because of their toxic, genotoxic and carcinogenic potential [1-5].

Polycyclic aromatic hydrocarbons are a class of organic chemical consisting of two or more fused aromatic rings and do not contain heteroatom or carry substituents. PAHs belong to the group of persistent organic pollutants (POPs). These are organic pollutant contaminants that are resistant to degradation, can remain in environment for a long period and have the potential to cause adverse environmental effects [6]. PAHs present in water intended for consumption generally come from coatings, tar, bitumen or water distribution pipelines [7]. Once ingested, polycyclic aromatic hydrocarbons are rapidly

\footnotetext{
*Corresponding author: marta.pogorzelec@pwr.edu.pl
} 
absorbed through the digestive tract and distributed in various tissues, and also the fetus. The mechanism by which these compounds act as carcinogens is still unclear and several theories have been formulated [7-9]. The International Agency for Research on Cancer (IARC) categorize benzo[a]pyrene and other PAHs in Group 1 (carcinogenic to humans), $2 \mathrm{~A}$ and $2 \mathrm{~B}$ (possible or probable carcinogens to humans) [7, 8].

In order to ensure health safety, it is necessary to carry out treatment processes of water intended for water supply purposes. The direct and immediate risk to health and life caused by the presence in water of pathogenic microorganisms makes it unthinkable to abandon the process of disinfection. As a result, the parameters proposed for the by-produscts of disinfection should not be so restrictive as to impair its use. And there comes another threat, although not all PAHs are highly harmful, in the processes of water treatment, they can form other dangerous compounds defined as disinfection by-products, which have high mutagenic and carcinogenic potential [10-12].

Organic micropollutants are present in water at very low concentrations, often below the detection limit, therefore samples should be concentrated prior to analysis. Semipermeable Membrane Devices (SPMDs) are designed for concentrating the hydrophobic organic compound present in water or air samples. SPMDs contain neutral lipid, the most often triolein, sealed within a thin wall of low density polyethylene (LDPE) tube. These membranes mimicking the biological membranes, thus allow selective diffusion of dissolved low molecular weight organic compounds, and their condensation in triolein. The technique is important for estimating risks associated with exposure of living organisms to contaminants, because allows to easily determine the time-weighted average concentration of the analytes dissolved and absorbed biologically for long periods of time [13-20]. Many studies have shown that this technique is appropriate for sampling water from various areas like the marine environment [21, 22], rivers [23-27] and lakes [15]. Long running water monitoring using SPMDs allows the assessment of changes in them over the years [23]. However, there is only a few publications describing the use of SPMDs for samples from a water treatment plant [28]. Extracts obtained through SPMDs are suitable for carrying out a variety of chemical and biological analysis [29-32]. The combination of semipermeable membrane devices and bioassays allows to determine the toxic and genotoxic potential of environmental samples. The effectiveness of the method was demonstrated for shortterm bioassays like Microtox ${ }^{\mathrm{TM}}[24,28]$ and Daphnia pulex test for assessing toxicity [24], as well as Vibrio harveyi test and MutatoxTM [24] for examination of water samples mutagenicity.

\section{Materials and methods}

\subsection{SPMDs deployment}

Semipermeable membrane devices of the standard configuration $(91.4 \mathrm{~cm}$ long, $2.5 \mathrm{~cm}$ wide, membrane thickness $70-95 \mu \mathrm{m}$, containing $1 \mathrm{ml}$ of $99 \%$ purity triolein) from ExposMeter AB (Tavelsjő, Sweden) were mounted on a metal spiders (Fig. 1.A.), then placed in perforated stainless steel containers (Fig. 1.B.), deployed in a surface water treatment plant called "Mokry Dwór", located in Lower Silesia, nearby Wrocław (Poland). Three places were chosen for sampling: A- pumping station "Czechnica" as a raw water input, B- pipeline with a stream of water just before ozone disinfection and C- clean water tank as a treated water output. Technological system of water treatment in "Mokry Dwór" is shown in Fig. 2. Characteristics of the sampling points is described below in Table 1. 
In the study, samples were taken monthly over a period of about five months (II-VI: February 2016-July 2016), which means that after each month membranes were exchanged. Exceptions were membranes labeled "III-IV" (March 2016-April 2016), which, due to technological problems at the water treatment plant, were remained in water for about eight weeks. There were also field blank control membranes for each month $(\mathrm{K})$, which were exposed to the same conditions like regular ones during instalation. Each membrane represents the state of water in a given month.
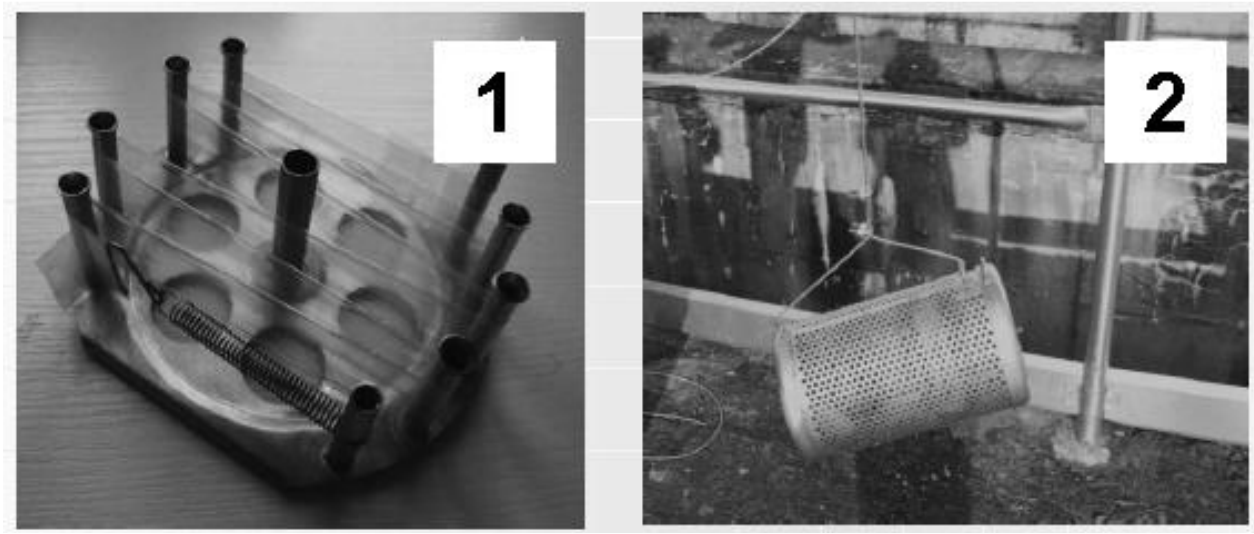

Fig. 1. Installation of semipermeable membrane devices (SPMDs): A- on metal spider, B- in stainless steel container.
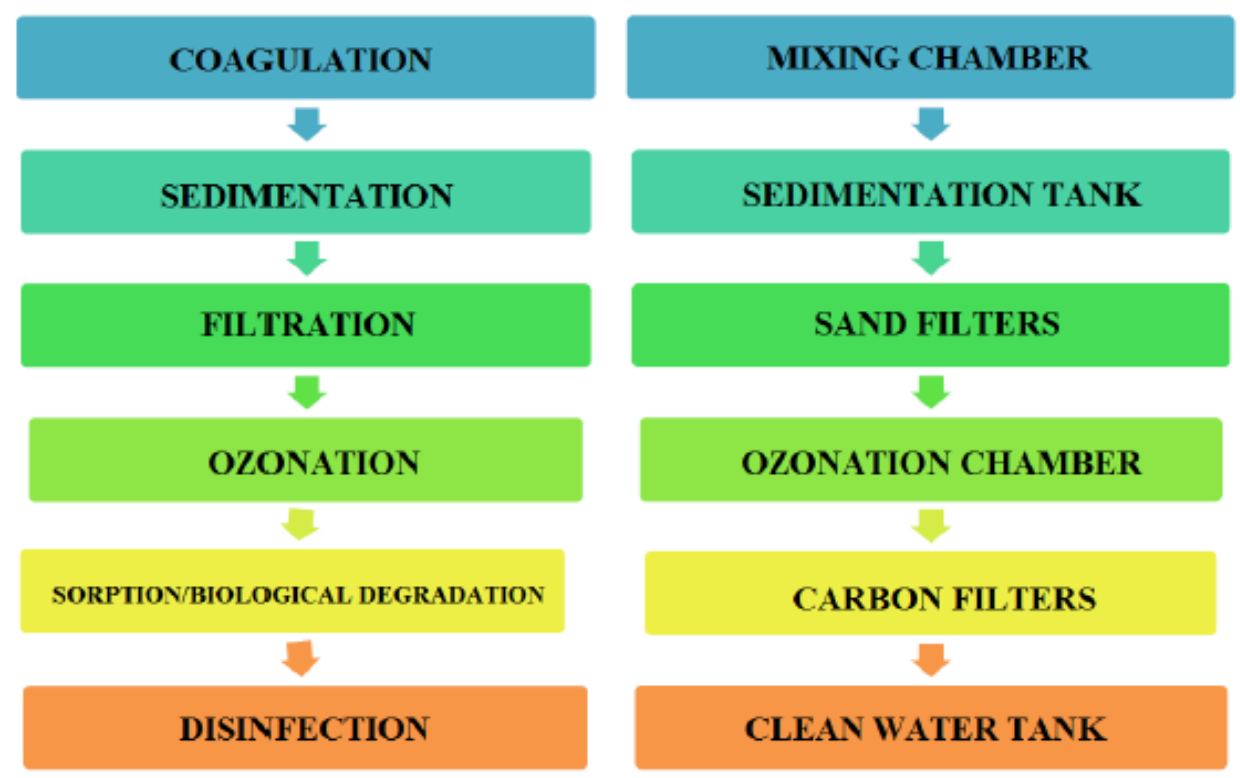

Fig. 2. Technological system used in "Mokry Dwór" Water Treatment Plant. 
Table 1. Characteristics of sampling places.

\begin{tabular}{|c|c|c|}
\hline $\begin{array}{c}\text { Sampling } \\
\text { place }\end{array}$ & $\begin{array}{c}\text { Symbol } \\
\text { used in } \\
\text { Results } \\
\text { tables }\end{array}$ & Characteristic \\
\hline $\begin{array}{c}\text { Pumping } \\
\text { station } \\
\text { "Czechnica": } \\
\text { raw water } \\
\text { input }\end{array}$ & A & $\begin{array}{c}\text { The water that flows into the pumping station "Czechnica" } \\
\text { is surface water without any treatment from the Olawa River. } \\
\text { The river has a length of 91.7 km and a catchment area of } \\
\text { 1167.4 square kilometers. The source of Otawa is in the Sudeten } \\
\text { Foreland at an altitude of about 315 meters above sea level. Its } \\
\text { composition is heavily dependent on the seasons. This water is } \\
\text { characterized by high content of suspensions, colloids and dissolved } \\
\text { organic compounds. In comparison with infiltrated or groundwater } \\
\text { is characterized by a low content of minerals such as manganese } \\
\text { and iron. }\end{array}$ \\
\hline $\begin{array}{c}\text { Pipeline: } \\
\text { water just } \\
\text { before } \\
\text { ozonation }\end{array}$ & B & $\begin{array}{c}\text { The water stream leaving the sand filter is free of suspensions, both } \\
\text { those present in the raw water input, as well as those formed during } \\
\text { the coagulation process. Organic compounds affecting the taste and } \\
\text { odor are still present. To remove them effectively on a carbon } \\
\text { filters, ozone is used to breaking them into smaller molecules, } \\
\text { which increases the biodegradability of organic compounds. } \\
\text { Disinfection by-products (generated during ozonation) are adsorbed } \\
\text { on a bed of coal or decomposed by a biomass in the bed. }\end{array}$ \\
\hline $\begin{array}{c}\text { Clean water } \\
\text { tank } \\
\text { water after } \\
\text { treatment }\end{array}$ & C & $\begin{array}{c}\text { In the clean water tank there is a water after complete treatment and } \\
\text { disinfection with chlorine dioxide. The water from this tank } \\
\text { is collected and pumped directly to the water supply network. This } \\
\text { water meets the requirements of water intended for human } \\
\text { consumption in accordance with the Regulation of the Minister } \\
\text { of Health in Poland. The dose of disinfectant dispensed before the } \\
\text { clean water tank must be large enough to prevent secondary } \\
\text { bacterial contamination of the water supply system. }\end{array}$ \\
\hline
\end{tabular}

\subsection{Samples preparation}

After each one month of sampling SPMDs were transported to the laboratory where mechanical and chemical cleaning was carried out according to the good SPMDs practice $[14,26,32]$. Then membranes were dialyzed separately in $130 \mathrm{~cm}^{3}$ of $n$-hexane to release compounds bounded in membrane. After 18 hours of dialysis in $18^{\circ} \mathrm{C}$ the solvent was replaced with fresh one $\left(130 \mathrm{~cm}^{3}\right)$ and dialysis was continued for another 8 hours. Then, both dialysates were mixed and n-hexane has been completely removed using the rotary evaporation. The same procedures were carried out for field blank membranes and for one unused, clean membrane (sample "K $\mathrm{K}_{0}$ "). In order to assess the effect of the solvent, $\mathrm{n}$-hexane in amount corresponding with the amount used per one membrane $\left(260 \mathrm{~cm}^{3}\right)$ was poured into round bottom flasks and also evaporated (sample "hex").

\subsection{Quantitative analysis of polycyclic aromatic hydrocarbons}

Dry extracts were drenched with $4 \mathrm{~cm}^{3}$ of cyclohexane, then evaporated to dryness under nitrogen and drenched with $1 \mathrm{~cm}^{3}$ of acetonitrile. Concentrations of PAHs were determined by high performance liquid chromatography (HPLC) with fluorescence detection on liquid chromatograph AT 1200 Agilent Technologies with fluorescent detector and spectrophotometric detector DAD. 
Operation conditions of liquid chromatograph

- separation on the chromatographic column:

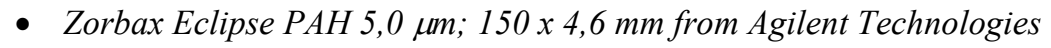

- volume of injection: $10 \mu \mathrm{l}$

- gradient elution with acetonitrile/water

- 50:50 $1 \mathrm{~min}$

- 100:0 $16 \mathrm{~min}$

- 100:0 $25 \mathrm{~min}$

- $50: 50 \quad 30 \mathrm{~min}$

- column temperature: $30^{\circ} \mathrm{C}$

- duration of the analysis: $30 \mathrm{~min}$

- mobile phase flow: $1 \mathrm{~cm}^{3} / \mathrm{min}$

- fluorescence detector parameters: wavelength: Ex 229 nm; Em. 400 nm

Table 2. Limits of detection and limit of quantification for polycyclic aromatic hydrocarbons determined on AT 1200 liquid chromatograph from Agilent Technologies with fluorescence detector.

\begin{tabular}{|c|c|c|c|}
\hline Compound & $\begin{array}{c}\text { Abbreviation } \\
\text { used in 'Results' } \\
\text { tables }\end{array}$ & $\begin{array}{c}\text { Limit of } \\
\text { detection (LOD) } \\
\text { [ug/ml] }\end{array}$ & $\begin{array}{c}\text { Limit } \\
\text { of quantification } \\
\text { [ug/ml] }\end{array}$ \\
\hline Naphthalene & $\mathbf{N}$ & 0.033 & 0.100 \\
\hline Acenaftylen & Ace & 0.067 & 0.200 \\
\hline Acenaften & Ac & 0.033 & 0.100 \\
\hline Fluoren & Fl & 0.007 & 0.020 \\
\hline Fenantren & Fen & 0.003 & 0.010 \\
\hline Anthracene & $\mathbf{A}$ & 0.003 & 0.010 \\
\hline Fluoranthene & Flu & 0.007 & 0.020 \\
\hline Pyrene & Pyr & 0.003 & 0.010 \\
\hline Benzo [a] anthracene & $\mathbf{B}[\mathbf{a}] \mathbf{A}$ & 0.003 & 0.010 \\
\hline Chryzen & $\mathbf{C h r}$ & 0.003 & 0.010 \\
\hline Benzo [b] fluoranthene & $\mathbf{B}[\mathbf{b}] \mathbf{F}$ & 0.007 & 0.020 \\
\hline Benzo [k] fluoranthene & $\mathbf{B}[\mathbf{k}] \mathbf{F}$ & 0.003 & 0.010 \\
\hline Benzo [a] pyrene & $\mathbf{B}[\mathbf{a}] \mathbf{P}$ & 0.003 & 0.010 \\
\hline Dibenzo [a, h] anthracene & $\mathbf{D}[\mathbf{a}, \mathbf{h}] \mathbf{A}$ & 0.007 & 0.020 \\
\hline Benzo [g, h, i] perylene & $\mathbf{B}[\mathbf{g}, \mathbf{h}, \mathbf{i}] \mathbf{P}$ & 0.007 & 0.020 \\
\hline Indeno [1,2,3-c, d] pyrene & $\mathbf{I}[\mathbf{1 , 2 , 3 - c , d ] P}$ & 0.003 & 0.010 \\
\hline
\end{tabular}

\section{Results and discussion}

The results of quantitative analysis of fifteen polycyclic aromatic hydrocarbons in water samples from various stages of potabilization are shown in Table 3 and Table 4. Polycyclic aromatic hydrocarbons are removed in a very efficient way during the water treatment process that is used in the "Mokry Dwór" Water Treatment Plant. The number, concentrations and complexity of PAHs are varied with each month. In all analyzed month, the amount of each detected PAH has decreased, in most cases even below the detection limit of the analytical method, with the progress of the treatment process. The results obtained for the solvent (n-hexane) used for samples preparation for analysis (cleaning, dialysis, dissolving material) indicates that it did not have any additional contaminants and its impact on the results was negligible. Similar 
conclusions can be drawn from the analysis of the results obtained for control membranes that have undergone exactly the same procedures as the regular membranes. This shows that the test material was not contaminated during the preparation of the samples for analysis.

Table 3. Concentrations of fifteen polycyclic aromatic hydrocarbons [ $\mu \mathrm{g} / \mathrm{sample}]$ in water samples from various stages of potabilization (A: pumping station- raw water input; B: pipeline-stream of water just before ozonation; $\mathrm{C}$ : clean water tank) and in control membranes (K), in particular months (II, III-IV).

\begin{tabular}{|c|c|c|c|c|c|c|c|c|c|}
\hline & Ko $_{\mathbf{0}}$ & II A & II B & II C & II K & $\begin{array}{c}\text { III-V } \\
\mathbf{A}\end{array}$ & $\begin{array}{c}\text { III-IV } \\
\text { B }\end{array}$ & $\begin{array}{c}\text { III-IV } \\
\mathbf{C}\end{array}$ & $\begin{array}{c}\text { III- } \\
\text { IV K }\end{array}$ \\
\hline $\mathbf{N}$ & n.d & $\mathbf{0 . 1 4 8}$ & $<$ LOD & $<$ LOD & $<$ LOD & $<$ LOD & $<$ LOD & n.d. & n.w. \\
\hline Ace & n.d. & n.d. & n.d. & n.d. & n.d. & n.d. & n.d. & n.d. & n.w. \\
\hline Ac+Fl & $<$ LOD $^{\text {a }}$ & $<$ LOD & $<$ LOD & $<$ LOD & $<$ LOD & $<$ LOD & $<$ LOD & n.d. & p.o. \\
\hline Fen & $\mathbf{0 . 0 9 6}$ & $\mathbf{0 . 9 8 0}$ & $\mathbf{0 . 4 1 2}$ & $\mathbf{0 . 0 8 0}$ & $<$ LOD & $\mathbf{0 . 2 7 6}$ & $\mathbf{0 . 0 7 1}$ & $\mathbf{0 . 0 6 0}$ & $\mathbf{0 . 0 4 1}$ \\
\hline $\mathbf{A}$ & $<$ LOD & $\mathbf{0 . 0 1 8}$ & $<$ LOD & n.d. & $<$ LOD & $<$ LOD & $<$ LOD & n.d. & p.o. \\
\hline Flu & $<$ LOD & $\mathbf{2 . 1 6 2}$ & $\mathbf{2 . 0 6 5}$ & $\mathbf{0 . 1 0 8}$ & $\mathbf{0 . 0 4 8}$ & $\mathbf{0 . 9 0 0}$ & $\mathbf{0 . 6 0 6}$ & $<$ LOD & p.o. \\
\hline Pyr & $\mathbf{0 . 0 2 4}$ & $\mathbf{0 . 8 1 8}$ & $\mathbf{1 . 0 4 4}$ & $<$ LOD & $<$ LOD & $\mathbf{0 . 5 5 2}$ & $\mathbf{0 . 3 2 1}$ & $\mathbf{0 . 0 1 6}$ & p.o. \\
\hline $\mathbf{B}[\mathbf{a}] \mathbf{A}$ & $<$ LOD & $\mathbf{0 . 1 4 5}$ & $\mathbf{0 . 2 8 3}$ & $<$ LOD & $<$ LOD & $\mathbf{0 . 1 3 0}$ & $\mathbf{0 . 1 6 0}$ & $<$ LOD & p.o. \\
\hline $\mathbf{C h r}$ & $<$ LOD & $\mathbf{0 . 1 7 8}$ & $\mathbf{0 . 1 6 3}$ & $<$ LOD & $<$ LOD & $\mathbf{0 . 1 7 1}$ & $\mathbf{0 . 1 7 3}$ & $<$ LOD & n.w. \\
\hline $\mathbf{B}[\mathbf{b}] \mathbf{F}$ & $<$ LOD & $\mathbf{0 . 0 5 4}$ & $\mathbf{0 . 0 3 5}$ & $\mathbf{0 . 0 2 8}$ & $<$ LOD & $\mathbf{0 . 0 5 0}$ & $\mathbf{0 . 0 4 4}$ & $<$ LOD & p.o. \\
\hline $\mathbf{B [ k ] F}$ & $<$ LOD & $\mathbf{0 . 0 2 4}$ & $\mathbf{0 . 0 1 0}$ & $<$ LOD & $<$ LOD & $\mathbf{0 . 0 3 8}$ & $\mathbf{0 . 0 3 6}$ & $<$ LOD & p.o. \\
\hline $\mathbf{B [ a ] P ~}$ & $<$ LOD & $<$ LOD & $<$ LOD & $<$ LOD & $<$ LOD & $\mathbf{0 . 0 3 9}$ & $\mathbf{0 . 0 1 0}$ & $<$ LOD & n.w. \\
\hline $\mathbf{D [ a , h ] A ~}$ & n.d. & $<$ LOD & $<$ LOD & $<$ LOD & n.d. & n.d. & $<$ LOD & n.d. & n.w. \\
\hline B[g,h,i]P & n.d. & $<$ LOD & $<$ LOD & n.d. & n.d. & $<$ LOD & n.d. & n.d. & n.w. \\
\hline $\begin{array}{c}\text { I[1,2,3- } \\
\mathbf{c d ] P ~}\end{array}$ & n.d. & $\mathbf{0 . 0 2 0}$ & $\mathbf{0 . 0 1 0}$ & n.d. & n.d. & $\mathbf{0 . 0 2 7}$ & $\mathbf{0 . 0 1 5}$ & n.d. & n.w. \\
\hline
\end{tabular}

${ }^{a}$ n.d-not detected

${ }^{\mathrm{b}} \mathrm{LOD}$ : limit of detection

Table 4. Concentrations of fifteen polycyclic aromatic hydrocarbons $[\mu \mathrm{g} / \mathrm{sample}]$ in water samples from various stages of potabilization (A: pumping station- raw water input; B: pipeline-stream of water just before ozonation; $\mathrm{C}$ : clean water tank), and in control membranes (hex, $\mathrm{K}$ ) in particular months $(\mathrm{V}, \mathrm{VI})$.

\begin{tabular}{|c|c|c|c|c|c|c|c|c|c|}
\hline & hex & V A & V B & V C & V K & VI A & VI B & VI C & VI K \\
\hline $\mathbf{N}$ & n.d. $^{\text {a }}$ & n.d. & n.d. & n.d. & n.d. & n.d. & $<$ LOD & $\mathbf{0 . 3 9 3}$ & n.d. \\
\hline Ace & n.d. & n.d. & n.d. & n.d. & n.d. & n.d. & n.d. & n.d. & n.d. \\
\hline Ac+Fl & $<$ LOD $^{\text {b }}$ & $<$ LOD & $<$ LOD & $<$ LOD & $<$ LOD & $<$ LOD & $<$ LOD & $<$ LOD & $<$ LOD \\
\hline Fen & $\mathbf{0 . 0 2 4}$ & $\mathbf{0 . 2 6 5}$ & $\mathbf{0 . 1 3 7}$ & $\mathbf{0 . 1 4 6}$ & $\mathbf{0 . 0 6 3}$ & $\mathbf{0 . 2 1 0}$ & $\mathbf{0 . 1 3 8}$ & $\mathbf{0 . 1 1 1}$ & $\mathbf{0 . 0 5 2}$ \\
\hline $\mathbf{A}$ & $<$ LOD & $<$ LOD & $<$ LOD & $<$ LOD & $<$ LOD & $<$ LOD & n.d. & $<$ LOD & $<$ LOD \\
\hline Flu & n.d. & $\mathbf{1 . 1 5 0}$ & $\mathbf{1 . 0 1 2}$ & $<$ LOD & $<$ LOD & $\mathbf{1 . 1 7 3}$ & $\mathbf{0 . 2 1 0}$ & $<$ LOD & $<$ LOD \\
\hline Pyr & $\mathbf{0 . 0 2 6}$ & $\mathbf{0 . 4 3 1}$ & $\mathbf{0 . 2 2 8}$ & $\mathbf{0 . 0 2 9}$ & $<$ LOD & $\mathbf{0 . 5 4 4}$ & $\mathbf{0 . 2 1 3}$ & $\mathbf{0 . 0 2 5}$ & $<$ LOD \\
\hline B[a] A & $<$ LOD & $\mathbf{0 . 1 2 2}$ & $\mathbf{0 . 0 7 7}$ & $<$ LOD & $<$ LOD & $\mathbf{0 . 1 4 0}$ & $\mathbf{0 . 0 4 4}$ & $<$ LOD & $<$ LOD \\
\hline Chr & $<$ LOD & $\mathbf{0 . 1 2 1}$ & $\mathbf{0 . 1 4 0}$ & $\mathbf{0 . 0 1 3}$ & n.d. & $\mathbf{0 . 1 4 2}$ & $\mathbf{0 . 1 2 2}$ & $<$ LOD & n.d. \\
\hline B[b]F & n.d. & $\mathbf{0 . 0 8 6}$ & $\mathbf{0 . 1 4 4}$ & $\mathbf{0 . 0 2 8}$ & $\mathbf{0 . 0 1 7}$ & $\mathbf{0 . 1 0 0}$ & $\mathbf{0 . 1 7 9}$ & $<$ LOD & $<$ LOD \\
\hline B[k]F & $<$ LOD & $\mathbf{0 . 0 4 5}$ & $\mathbf{0 . 0 5 8}$ & $<$ LOD & $<$ LOD & $\mathbf{0 . 0 5 9}$ & $\mathbf{0 . 0 4 7}$ & $<$ LOD & $<$ LOD \\
\hline B[a]P & n.d. & $\mathbf{0 . 0 2 0}$ & $<$ LOD & $<$ LOD & $<$ LOD & $\mathbf{0 . 0 2 9}$ & $<$ LOD & $<$ LOD & n.d. \\
\hline D $[\mathbf{a , h}] \mathbf{A}$ & n.d. & $<$ LOD & n.d. & n.d. & n.d. & n.d. & $<$ LOD & $<$ LOD & n.d. \\
\hline B[g,h,i]P & n.d. & n.d. & n.d. & n.d. & n.d. & $<$ LOD & $<$ LOD & n.d. & n.d. \\
\hline I[1,2,3-cd]P & n.d. & $\mathbf{0 . 0 3 5}$ & $\mathbf{0 . 0 2 2}$ & n.d. & n.d. & $\mathbf{0 . 0 4 7}$ & $\mathbf{0 . 0 3 2}$ & n.d. & n.d. \\
\hline
\end{tabular}




\section{Conclusions}

Due to the low concentration of micropollutants in water, it is necessary to fit appropriate technique for concentration of them, to be detectable during the chemical and biological analysis. This study indicates that the use of semipermeable membrane devices can be an effective tool for the analysis of drinking water, in which organic micropollutants are found at very low concentrations. The proposed method uses SPMDs, which are placed directly at the place of sampling, what eliminates logistical problems.

Presented study shows, that water treatment processes carried out in "Mokry Dwór" Water Treatment Plant effectively reduce the concentration of polycyclic aromatic hydrocarbons, which may be a precursor of many dangerous substances.

Nevertheless, to accurately assess the changes in water with the progress of the treatment process, chemical analysis for the detection of other potential compounds in the water, with emphasis on disinfection by-products, including trihalomethanes, should be extended. Furthermore, to assess the effects of substances contained in test samples on living organisms, biological studies including toxicity and genotoxicity tests should be carried out.

What is more, to be able to draw accurate conclusions about the impact of weather conditions on the water, analysis should be conducted for an extended period, at least throughout the year.

The research financed by the funds of the Ministry of Science and Higher Education for young scientist and doctoral students order number: B50557.

\section{References}

1. J. Fawell, M.J. Nieuwenhuijsen, Brit. Med. Bull. 68, 199-208 (2003)

2. L. Kowal, M. Świderska-Bróż, Water treatment (PWN, Warszawa, 2007) (in Polish)

3. M. Świderska-Bróż, Micropollutants in aquatic environment (Wydawnictwo Politechniki Wrocławskiej, Wrocław, 1993) (in Polish)

4. T.M. Traczewska, Biomonitoring of the mutagenicity of microcontaminants in drinking water (Oficyna Wydawnicza Politechniki Wrocławskiej, Wrocław 2002) (in Polish)

5. T. Ohe, T. Watanabe, K. Wakabayashi, Mutat. Res. 567, 109-149 (2004)

6. J.C. Igwe, P.O. Ukaogo, Journal of Natural Sciences Research 5, 7, 117-132 (2015)

7. S. Scicca, G.O. Conti, Mediterr. J. Nutr. Metab. 2, 157-162 (2009)

8. I. Abdel-Shafy, M.S.M. Mansour, Egypt J. Petrol. 25, 107-123 (2016)

9. H.T. Rengarajan, P. Rejendran, N. Nanakumar, B. Lokeshkumar, P. Rajendran, I. Nishigaki, Asian Pac. J. Trop. Biomed. 5, 3, 182-190 (2015)

10. D.B. McGregor, Methods for Assessing the Effects of Mixtures of Chemicals, 523-542 (1987)

11. S.D. Richardoson, Trend Anal. Chem. 22, 666-684 (2003)

12. C. Zani, D. Feretti, A. Buschini, P. Poli, C. Rossi, L. Guzella, F. Di Caterino, S. Monarca, Mutat. Res. 587, 26-37 (2005)

13. J.N. Huckins, J.A. Lebo, M.W. Tubergen, G.K. Manuweera, V.L. Gibson, J.D. Perry, United States Patent, Patent Number 5, 098573 (1992)

14. J.N. Huckins, Fundamentals of SMPDs. Monitors of organic chemicals in the environment, Springer 29-43 (2006) 
15. Y. Lu, Z. Wang, J. Huckins, Aquat. Toxicol. 60, 139-153 (2002)

16. B. Vrana, G. Schüürmann, Environ. Sci. Technol. 36, 290--296 (2002)

17. L. Šetková, J. Hajšlová, P.-A. Bergqvist, V. Kocourek, R. Kazda, P. Suchan, J. Chromatogr. A 1092, 170-181 (2005)

18. K. Booij, H.M. Sleiderink, F. Smedes, Environ. Toxicol. Chem. 17, 1236-1245 (1998)

19. B. Vrana, A. Paschke, P. Popp, G. Schüürmann, Environ. Sci. Pollut. R 8, 27-34 (2001)

20. J.N. Huckins, G.K. Manuweera, J.D. Petty, D. Mackay, J.A. Lebo, Environ. Sci. Technol. 27, 2489-2496 (1993)

21. A. Marrucci, B. Marras, S.S. Campisi, M. Schintu, Mar. Pollut. Bull. 75, 69-75 (2013)

22. K. Pazdro, Rocz. Ochr. Sr. 4, 189-205 (2002)

23. J.F. Mueller, M.R. Mortimer, J. O’Brein, T. Komarova, S. Carter, Mar. Pollut. Bull. 63, 73-76 (2011)

24. D. Sabaliūnas, J.R. Lazutka, I. Sabaliuniene, Environ. Pollut. 109, 251-265 (2000)

25. D. Sabaliūnas, A. Södergren, Environ. Pollut. 96, 195-205 (1997)

26. M. Schaefer, Pharmaceutical and Personal Care Products in the Sacramento River-Report, Standard Operating Procedure: Preparation of SPMDs for Dialysis, SOP E-14 (2009)

27. W.L. Cranor, D.A. Alvarez, S.D. Perkins, G.A. Tegerdine, R.C. Clark, J.N. Huckins, Use of semipermeable membrane device (SPMD)technology for a probabilistic assessment of hydrophobic organic contaminants in selected reaches of Virginia rivers (U. S. Geological Survey, 2005)

28. G. Gilli, T. Schiliro, Pignata, D. Traversi, E. Carraro, C. Baiocchi, R. Aigotti, D. Giacosa, E. Fea, Chemosphere 61, 1691-1699 (2005)

29. B. Karacik, O.S. Okay, B. Henkelmann, G. Pfister, K.-W. Schramm, Mar. Pollut. Bull. 70, 258-265 (2013)

30. J.D. Petty, J.N. Huckins, S.B. Jones, T.P. Boyle, Chemosphere 41, 311-321 (2000)

31. E.S. Emelogu, P. Pollard, C.D. Robinson, F. Smedes, L. Webster, I.W. Pliver, C. McKenzie, T.B. Seiler, H. Holler, C. F. Moffat, Chemosphere 90, 210-219 (2013)

32. D. Alvarez, Guidelines for the use of the semipermeable membrane device (SPMD) and the polar organic chemical integrative sampler (POCIS) in environmental monitoring studies, (U.S. Geological Survey, Techniques and Methods 1-D4 2010) 